\title{
Assessment of Credit Risk Approaches in Rela- tion with Competitiveness Increase of the Banking Sector
}

\author{
Cipovová Eva, Belás Jaroslav
}

\begin{abstract}
The article is focused on a presentation and analysis of selected methods of credit risk management in relation with competitiveness increase of the banking sector. The article is defined credit risk approaches under the Basel III gradually.

Aim of this contribution constitutes various methods of credit risk management and effects of their usage on regulatory capital amount in respect of corporate exposures.

Optimal equity amount in relation to the risk portfolio presents an essential prerequisite of performance and competitiveness growth of commercial banks. Gradually capital requirements using Standardized Approach and Internal Based Approach in a case of used and unused techniques of credit risk reduce has been quantified.

We presume that sophisticated approach means significant saving for bank's equity which increases competitiveness of banking sector also. Within the article, quantification of capital savings in case of Standardized (with and without assigned external ratings) and Foundation Internal Based Approach at the selected credit portfolio has been effected.
\end{abstract}

Key words: credit risk, Standardized approach, FIRB approach, expected and unexpected loss, leverage ratio, capital adequacy, Basel III.

\section{INTRODUCTION}

NBCA (New Basel Capital Accord) is a regulatory business framework of commercial banks and has aims to maintain stability and integrity of the banking system as much as possible. However, in recent years regarding the state, where the banking system not only fulfilling its mission, but by its instruments, system imbalances have further increased.

According Belás (Jaroslav Belás \& co-authors., 2010, p. 304) reason for this is the financial crisis, which by a regulated part of the financial system and just after the implementation of NBCA rules was hit. Financial regulation is strongly procyclical, and rather than reducing systemic risk, financial regulation is deeped and threated the risk of the global financial system. The global crisis has shown that the deterioration in the performance of the banking sector due to the failure credit risk management by all participants of the system caused deterioration in bank liquidity and the subsequent intervention by the states. Today's set-up system requirements tend to reduce the ratio to total equity (banks employ risk managers, whose task is to optimize the amount of capital to risk). 


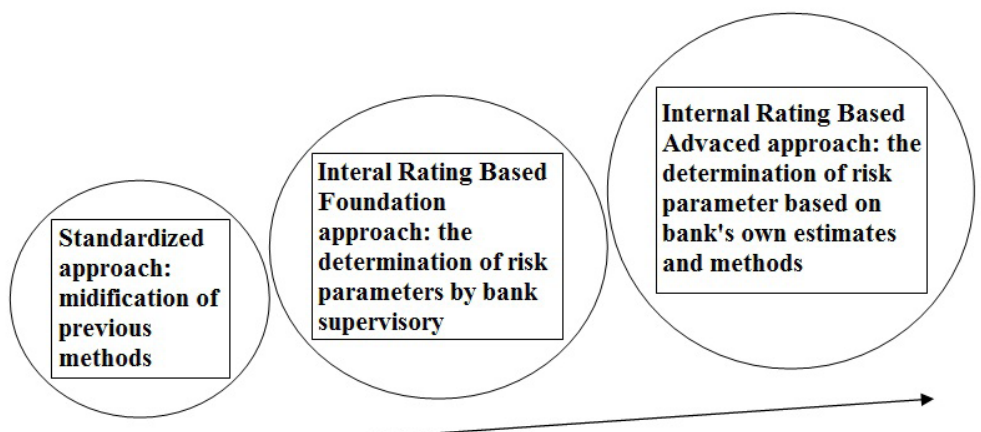

Possible reduction of bank's capital requirements

Fig. 1 - 'The approaches to risk, measurement by NBCA. Source: Slovenská sporitelina, 2010, p.4

According to Holman (Holman, 2009), problem of NBCA is its pro-cyclical nature, which causes excessive growth of assets in times of economic boom. The prevailing optimism makes the investment risks underestimated and credit demand is higher. Banks and ratings agencies underestimates the credit risk because of customers prosper and their low probability of default. Credit risk models work with information, which show more favorable picture of the client in times of prosperity as in times of recession, and credit risks are revalued upwards. If the probability of default is calculated from a short series of historical data, pro-cyclical nature of NBCA is increased. This trend raises underestimating credit risks in the case of boom and its tendency to overestimate in the case of economic recession. One solution is to use the additional capital requirement in the form of leverage ratio, i.e. equity share to-risk non-weighted assets, which may stop the excessive expansion of bank assets. Banks are in recessionary times more capital to cover losses.

According to Polouček (Polouček \& co-authors, 2006, p. 289), reduction of the required capital in NBCA will apply only to banks that use sophisticated internal models, so the possibility of reducing capital requirements banks will have only large banks with sufficient financial resources.

Many experts claim that there are many ways to remedy this problem. One of them is a return to simplicity, but which would exclude the flexibility of credit risk evaluation. Another approach to solve the procyclicality in Basel II is the improvement of existing requirements by more conservative risk parameters of the requirements for internal rating models, longer time series, the use of backtesting in rating models, or more frequently comparing the expected and realized the borrower defaults (Jaroslav Belás \& co-authors, 2010).

In addition to the Basel approach to measure credit risk, there are many statistical and mathematical methods that have significant part of the rating models in the commercial banks and in the external credit rating agencies also.

This article aims to bring critical view on the credit risk evaluation of Basel Committee and demonstrate that the use of advanced methods will lead to capital savings by calculating capital requirements under basic concepts and their comparison with the advanced methods of credit risk management of NBCA. 
While preparing this article, we have used the methods of secondary analysis, using foreign periodicals and professional literature. In the secondary analysis, we have used cross-sectional analysis. General conclusion during a critical perspective on credit risk management by inductive method has been inferred. In the empirical analysis, the methods of measurement has been used, where the results of capital requirements for two standardized methods and one advanced method of Basel III has been calculated. Finally, the methods of comparison have been applied, where we questioned which method provides the highest demand for capital and compared with other methods. The aim was to determine whether more sophisticated methods reduce the requirement for capital adequacy of banks.

\section{RESULTS}

\subsection{Components of credit margins}

In calculating of capital adequacy is necessary to take into account the credit risk distribution and divides to the concepts of expected and unexpected loss. The expected loss of an existing financial loss, according to Czech National Bank No. 9/2002 (ČNB, 2002) bank must make adjustments and reserves, which form a "cushion" to cover expected losses. Unexpected loss means the bias actually realized losses from unexpected losses. (see Fig. 1.)

For the purpose of covering unexpected losses, the bank must keep its capital at least equal to regulatory capital requirements. To make concept of regulatory capital requirements really relevant, it is necessary to get near the concept of unexpected loss and economic capital. Capital Bank should in any case reflect an unexpected loss.

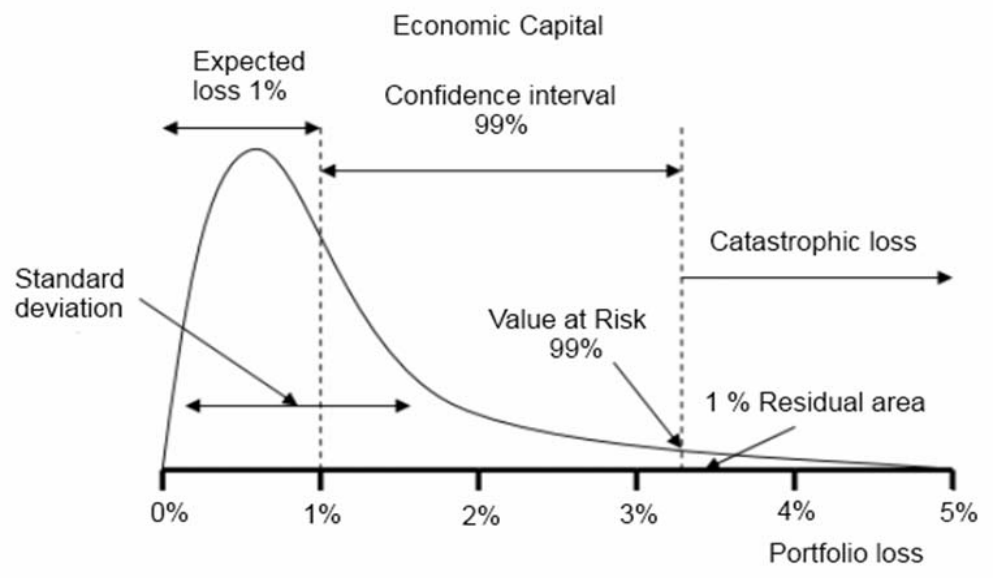

Fig. 2 - Covering expected and unexpected losses. Source: Basel Committee on banking supervision, 2005

Figure above shows that the portfolio expected loss is $1 \%$. It is covered from reserves, which are counted as expenses. Unexpected losses can be covered by economic capital. VaR (Value at Risk) summarizes the worst loss for a specified time horizon at a given confidence interval 
(99\%). Terminal region reflects catastrophic losses; its probability is $1 \%$. Component of expected and unexpected loss is the credit spread components together, thus payment for taking credit risk.

\subsection{Methods of credit risk measurements for capital adequacy use}

The Basel III concept is mainly aimed on ensuring the stability and competitive environment on financial markets, and makes bank's management more liable and responsible. One way on how to reach this stability, is through sensitive risk measurement and improvement their risk management by creating efficiencies of regulatory capital requirements for banks, which are active internationally, as well as efficient use of capital to cover potential risks.

Basel Committee allows the bank to choose between two methodologies for calculating capital requirements with regard to credit risk. First of them is Standardized Approach (STA), whereby assets and assign risk weights of their individual exposures by assuming the rating from External Credit Assessment Institution (ECAI) or from export agencies (ECA - Export Credit Agencies) is evaluated. Second one is called Internal Rating Based Approach and is advanced one. It uses own instruments for their own internal estimates of risk parameters, which are counted in calculating of capital requirements of the exposure. These instruments must be consistent with the qualitative requirements of Basel III and national regulators also. Internal Rating Based Approach (IRB) is divided in two separate methodology parts - Foundation Internal Rating Based Approach (FIRB) and Advanced Internal Rating Based Approach (AIRB) with regard to the range of estimated parameters. Within Standardized Approach, banks evaluate only one parameter (PD - Probability of Default) by their own internal model and other characteristics must be determined by national regulator. Within Advanced Internal Rating Approach, banks could estimate parameters such as Loss Given Default (LGD) and Exposure at Default (EaD) and Maturity (M) by their own. (Sivák and Gertler, 2006)

IRB approach is provided different risk-weighted functions for different exposure's classes (for example corporate or retail exposures) to calculate capital requirements.

\subsubsection{Standardized approach}

The Standardized Approach determines the risk weights for calculation of capital requirements with respect to each category of claims. These include claims against the state and central banks, public sector entities, corporate, retails, claims secured by property, off balance sheet items, securitized exposures, high risk and defaulted claims. (ČNB, 2007)

Capital requirement of the investment portfolio equals to $8 \%$ of the total value of risk-weighted exposure. Risk weights in relation with business exposure are shown below:

Tab. 1 - A risk weight to corporate exposures within STA approach. Source: Basel Committee on banking supervision, 2006.

\begin{tabular}{|c|c|c|c|c|c|}
\hline Rating & AAA - AA- & A+ - A- & BBB + - BB- & Less than BB- & Without rating \\
\hline Risk weight & $20 \%$ & $50 \%$ & $100 \%$ & $150 \%$ & $100 \%$ \\
\hline
\end{tabular}


Corporate claims which are without assigned external rating are automatically assigned a risk weight $100 \%$, what is very common for Czech Republic. However, the regulator has the competence to increase this risk weight's value, eventually extended it to an externally rated companies. This means that, regulator could assign all claims $100 \%$ risk weight regardless of external rating.

Assumption of the external rating for any exposure entails regulatory requirements and approval rating system with external rating agencies. Risk weights in STA approach are calibrated on the rating framework of Standard \& Poor's. Other agencies must meet six basic criteria for the award as follows: objectivity, independence, and international access, transparency of the rating, disclosure of the methodology, publication of current results and sources of credit rating agencies. Another condition is to be recognized and registered by local regulators. In comparison with Basel III, corporate exposure categories in STA approach are assigned to the six credit quality degrees in the Czech Republic, where it is possible to induce external rating of registered rating agencies. In the Czech Republic, risk weights are as follows: (ČNB, 2007a)

Tab. 2 - Risk weights for exposures. Source: Basel Committee on banking supervision, 2005.

\begin{tabular}{|c|c|c|c|c|c|c|}
\hline Credit rating & AAA - AA & A+ - A- & $\begin{array}{c}\text { BBB } \\
- \text { BBB- }\end{array}$ & BB+ - B- & $\begin{array}{c}\text { Less } \\
\text { than B- }\end{array}$ & $\begin{array}{c}\text { Without } \\
\text { rating }\end{array}$ \\
\hline $\begin{array}{c}\text { Risk weights } \\
\text { for states }\end{array}$ & $0 \%$ & $20 \%$ & $50 \%$ & $100 \%$ & $150 \%$ & $100 \%$ \\
\hline $\begin{array}{c}\text { Risk weights } \\
\text { for banks }\end{array}$ & $20 \%$ & $50 \%$ & $100 \%$ & $100 \%$ & $150 \%$ & $100 \%$ \\
\hline $\begin{array}{c}\text { Risk weights } \\
\text { for corporate }\end{array}$ & $20 \%$ & $50 \%$ & $100 \%$ & & $150 \%$ & $100 \%$ \\
\hline
\end{tabular}

Big challenge for regulators is correct assessment of rating agencies (primarily of the newer one). Regulators are also criticized mainly in the case of problems regarding bad awarded credit rating. At the same time, regulator is also responsible for mapping, i.e. assign a rating to each risk weights of STA approach. Rating evaluation of each rating agency could be different but result's value must have same information. However, it is extremely important for agencies provide roughly the same ratings. Otherwise, banks would be able to exploit this kind of situation, choose the agency with the mildest and most convenient evaluation to reduce the capital requirement. In connection with the financial crisis in the capital markets credit rating agencies are considered as one of the main culprits. Regarding to the issue of failure of external credit rating agencies, various measures were adopted and by relevant institutions (EU Commission, the Securities and Exchange Commision) were addressed. It is interesting to observe that even though purpose of the rating isn't examine the financial performance or credit risk of investment vehicle; investors are essentially governed by their decisions on this indicator. We see a problem mainly in the lack of transparency and sophisticated instruments which by investors are often misunderstood. On the other hand, it is interesting to observe the fact that the rating organizations are appreciating other businesses but in a competitive environment are absolutely not cooperating and have enormous influence. (Belás and Cipovová, 2011) 


\subsubsection{IRB approach}

This advanced approach is based on the own internal assessment of unexpected losses (UL) and expected losses (EL). Bank must hold sufficient capital accepted by regulator based on the frequency of bank's insolvency from credit losses. For first exposures using risk-weighted functions capital requirements are calculated. These exposures reflect the risk incurred by deviating from the expected risk. Generally they are defined as the volatility of EL. The expected losses are calculated separately for non-defaulted claims and are the best estimates for defaulted exposures. Using foundation or advanced IRB approach, categorization of exposures into one of five asset classes (or even further subclasses) have to be established by banks. For each of these three basic elements classes are provided: (ČNB, 2007b)

- Risk parameters

- Probability of Default (PD) determines the probability of borrower's default during next 12 months

- Exposure at Default (EaD) determines the bank's loss amount that occurs when the borrower defaults

- Loss Given default (LGD) determines the changes of loan repayment in case of repayment's failure by borrower

- Maturity (M)

- Risk weighted function for capital requirement calculation (K)

- Minimum requirements for use IRB approach must be met by bank

Indicator of expected loss (EL) is calculated as multiples of the outcome of all three indicators (Basel Committee on banking supervision, 2005):

$$
E L=P D^{*} E a D^{*} L G D
$$

IRB approach is two-dimensional, i.e. that takes into account both - the borrower and the transaction. This means that if the probability of default on the debtor, and other risk elements are focused on the transaction. Internal ratings method is divided into two broad lines of credit risk measurement:

Aim of internal ratings of banks is classified exposures into the categories, the subsequent assessment of its characteristics and determines the degree of internal rating. For this degree is estimated the likelihood of default, which is an important input to the function of capital requirements. Described procedure is shown as follows (Ctibor Pilch, 2008):

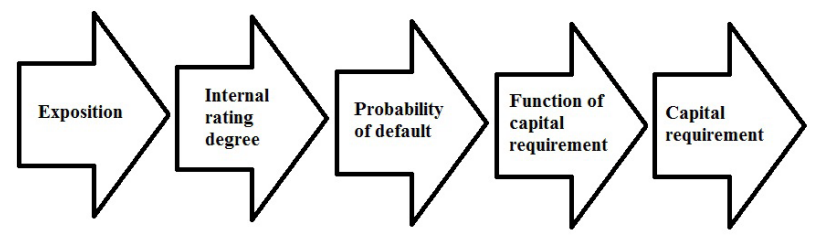

Fig. 3 - Scheme of procedure for determination of internal rating. Source: Own Source 
A disadvantage of internal ratings is their complexity, often misunderstanding and lack of transparency. It has been shown that statistical methods for measuring risk give biased predictions underestimate the risks associated with a decrease of different assets.

One of the reasons of unstable operation of the financial system is imperfect risk-measurement methodologies used by using statistical models to measure and predict risks, which don't give reliable results and even contribute to pro-cyclical changes in the financial lever banks, i.e. in the entire financial system. (Knápková and Pavelková, 2010)

\subsection{Capital requirement calculation for corporate exposures by individual methods of credit risk management}

Capital requirement to cover unexpected losses by using IRB approach is subordinated on own estimates of risk parameters or the assumption from the regulator. We use formulas in calculation set by the regulator as follows: (ČNB, 2007c)

$$
\text { Correlation }(R)=0,12 * \frac{\left(1-e^{(-50 * P D)}\right)}{\left(1-e^{(-50)}\right)}+0,24 *\left[1-\frac{\left(1-e^{(-50 * P D)}\right)}{\left(1-e^{(-50)}\right)}\right]
$$

A correlation is a dependence of debtor's assets on the overall state economy conditions and reflects the independence between each value of debtor's assets also. A correlation of debtor's assets is dependent on the banking portfolio segmentation and exposure categorization. Correlation of large company's portfolio is higher compared to the retail portfolio, because companies on the general state economy conditions are more depended.

According Conford (Conford, 2005) correlation is a decreasing function of PD in order to reflect the fact that the corporate credit risk with higher level of PD is more affected by idiosyncratic factors such as systematic macroeconomic factors.

$$
\text { Maturity adjustment }(b)=(0.11852-0.05478 * \ln (P D))^{2}
$$

The capital requirement is adjusted to different maturity assets. Based on regression model and usage of credit risk model KMV Portfolio Manager (BCBS, 2005) function (b) is decreasing function of PD because tools with lower PD have higher ability reduce rating than tools with higher values of PD during its time period. With increasing PD, function (b) to minimum value of 0,014 is decreased and for defaulted debtors, it is decreased to 0,1185222.

At this point, we could calculate the capital requirement per exposure's unit at default. It counts loss incurred due to claim's default and its maturity (formula (4)):

$$
\operatorname{Capital}(K)=\left(L G D * N\left(\frac{1}{\sqrt{1-R}} * G(P D)+\frac{\sqrt{R}}{\sqrt{1-R}} * G(0,999)-P D x L G D\right) * \frac{(1+(M-2,5) * b)}{(1-1,5 * b)}\right.
$$

Where, PD is the probability of default, LGD the loss given default, $\mathrm{N}(\mathrm{x})$ is a function of the normal distribution of random variable $(\mathrm{N}(0,1)), \mathrm{G}(\mathrm{z})$ is the inverse cumulative distribution function for a standard random variable, where $\mathrm{N}(\mathrm{x})=$ a variable $\mathrm{R}$ is the correlation of systemic risk, $\mathrm{M}$ is effective maturity and $\mathrm{b}$ is adjusted maturity. 
PD and LGD are given in tenths, respectively in percentages; $\mathrm{M}$ is given in years or part of the year. For inverse cumulative distribution function confidence interval $99,9 \%$ is defined and serves as a calibration component in the rating model. Apparently a high and conservative value of this interval was determined with respect to possible error in determining the estimated PD, LGD and EaD (financial institutions expect value which would be more than Tier 1 and Tier 2 on average once every one thousand years). The effective maturity M is set in 2,5 years, respectively six months for repo operations within foundation IRB approach. Generally, the shorter the maturity is the lower credit risk and less capital requirement is caused and vice versa. Using own calculations, the effective maturity is limited by range from below 1 year and above 5 years. Short-term and liquid exposures, which have less than one year maturity (OTS instruments, repo operations), one daily basis are revalued. If the instrument is provided payments, the effective maturity is calculated by formula as follows:

The effective maturity $(M)=\frac{\sum_{t} t^{*} C F_{t}}{\sum_{t} C F_{t}}$

Otherwise, conservative approach is proceeded by bank and as the effective maturity, the remaining time in which the debtor must repay its commitment is chosen. Usually, it is a nominal maturity instrument.

The last step is the actual risk-weighted assets calculation:

$$
R W A=K^{*} 12,5 * \text { scaling factor } * E a D
$$

$\mathrm{EaD}$ is given in a particular currency without reduction by rectifying items and depreciations in case of balance sheet items. Off-balance sheet items are re-adjusted by conversion factors, which within advanced approach could be estimated by bank.

Value 12,5 is called the risk weighted assets increase factor and represents inverted value of the minimum capital adequacy, i.e. $1 / 8 \%$. This constant factor is used mainly in order to keep the original aggregate level of capital risk weights when different categories of risk weights of exposures are compared and calibrated. An important component of RWA calculation is scaling factor. Its purpose is to maintain a certain level of capital, but it has also the motivational character, which forces banks to move to advanced and more sensitive methods of risk management due to the fact that the additional "tax" might not touched the bank so much. Currently, the best estimate of this factor is 1,06 and leads to further increase of minimum required capital.

$$
C R=0,08 * R W A
$$

Basel III provides for governments, banks and corporate exposures these LGS value as follows:

- Senior claim - $45 \%$ LGD

- Subordinate claim - 75 \% LGD

If the bank doesn't meet the requested requirements for own estimating PD of specialized loan exposures, their internal rating estimates must be adjusted by regulator's provided categories and risk weights. 
Within the focus of this article, basic research to compare credit risk approach in commercial bank under Basel II has been carried out and changes in the regulatory capital amount using different risk weighted functions of basic and advanced methods for credit risk management under Basel II has been quantified by changing of the corporate portfolio structure from the most creditworthy to defaulted exposures. Using each category of rating scale with given underlying prerequisites, capital requirements for concrete approaches has been calculated. As a source of rating scale's category and their related PD values, information from Standard \& Poor's has been used, namely One-Year Global Corporate Default Rates By Rating Modifier for the period 1981-2010. (Annual Global Corporate Default Study And Rating Transitions, 2010)

Value can be seen in the table as follows:

Tab. 3 - Rating scale's category and their related PD values. Source: modified Standard \& Poor's, 2010.

\begin{tabular}{|c|c|c|c|c|c|c|}
\hline Rating & $\mathrm{AAA}$ & $\mathrm{AA}+$ & AA & AA- & \multirow{2}{*}{1} & \multirow{12}{*}{ 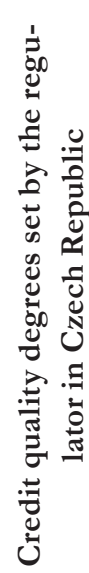 } \\
\hline PD & 0,00001 & 0,00001 & 0,0001 & 0,0003 & & \\
\hline Rating & & A+ & A & A- & \multirow{2}{*}{2} & \\
\hline PD & & 0,0005 & 0,0007 & 0,0008 & & \\
\hline Rating & & $\mathrm{BBB}+$ & $\mathrm{BBB}$ & BBB- & \multirow{2}{*}{3} & \\
\hline PD & & 0,0016 & 0,0026 & 0,0031 & & \\
\hline Rating & & $\mathrm{BB}+$ & $\mathrm{BB}$ & BB- & \multirow{2}{*}{4} & \\
\hline PD & & 0,0067 & 0,0088 & 0,0147 & & \\
\hline Rating & & $\mathrm{B}+$ & B & B- & \multirow{2}{*}{5} & \\
\hline PD & & 0,0247 & 0,0717 & 0,0999 & & \\
\hline Rating & & & & $\mathrm{CCC} / \mathrm{C}$ & \multirow{2}{*}{6} & \\
\hline PD & & & & 0,2356 & & \\
\hline
\end{tabular}

Determined portfolio includes corporate exposures with a total value 100 mil. Kč (EaD), regulator provided LGD (0.45 for senior debt and $0.75 \%$ for subordinated debt) and effective maturity of 2,5 years (ČNB, 2007). Calculations with $99 \%$ confidence interval were counted. Only one input variable, probability of default was changed 2010 times within the range from 0,0001 to 0,23 .

Using Standardized approach (STA) without assigned external rating which is used very often in the Czech Republic, capital requirement has been calculated. Enumeration is very simple because of its constancy. Formula reads as RWA $=\mathrm{EaD} * \mathrm{RW}$, which in our case the amount

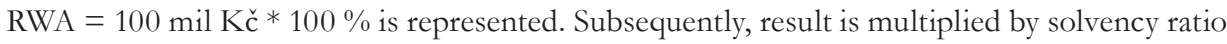
of $8 \%$, which gives us the final amount of capital required 8 million Kč (CK $=100 \% * 100$ mil. Kř $* 8 \%$ ).

Using Standardized approach with assigned external rating capital adequacy calculation has been performed. Here bank could use the possibility to change risk-weighted assets. Results are shown in the table as follows: 
Tab. 4 - Capital requirements using Standardized approach with assigned external rating. Source: Own Source

\begin{tabular}{|c|c|c|c|c|c|}
\hline EAD in mil. Kč & PD & $\begin{array}{c}\text { Rating } \\
\text { Standard and } \\
\text { Poor's }\end{array}$ & RW & RWA & $\begin{array}{c}\text { Capital } \\
\text { adequacy in } \\
\text { mil. Kč }\end{array}$ \\
\hline 100 & 0,0001 & AAA & 0,2 & 20 & 1,600 \\
\hline 100 & 0,006 & A+ & 0,5 & 50 & 4,000 \\
\hline 100 & 0,0017 & BBB+ & 1 & 100 & 8,000 \\
\hline 100 & 0,0255 & B + & 1,5 & 150 & 12,000 \\
\hline
\end{tabular}

Using advanced approach such as foundation internal rating based approach where probability of default is assigned by own rating assessment, capital adequacy has been calculated. This approach doesn't use external ratings but bank's own estimates. Process of capital requirements computation for senior exposures with 0,45 LGD is shown in table 5 and for subordinate exposures with 0,75 LGD is shown in table 6 as follows:

Tab. 5 - Capital requirements using Foundation Internal Rating Based Approach. Source: Own Source

\begin{tabular}{|c|c|c|c|c|c|c|c|c|c|}
\hline & \multirow{2}{*}{$\begin{array}{c}\text { LGD } \\
\text { maturity }\end{array}$} & \multirow{2}{*}{$\begin{array}{r}0,45 \\
2,5\end{array}$} & & & & & & & \\
\hline & & & & & & & & & \\
\hline EAD & PD (\%) & rating & $\begin{array}{c}\text { Correla- } \\
\text { tion }\end{array}$ & $N(x)$ & b & RW & RWA & $\begin{array}{c}\text { Capital } \\
\text { adequacy }\end{array}$ & $\mathrm{EL}=\mathrm{PD} * \mathrm{LGD}$ \\
\hline 100 & 0,0001 & $\mathrm{AAA}$ & 0,239401 & $-2,531$ & 0,388 & 0,08 & 7,9842 & 0,63874 & 0,0045 \\
\hline 100 & 0,0006 & $\mathrm{~A}+$ & 0,236453 & $-1,987$ & 0,276 & 0,232 & 23,237 & 1,85893 & 0,027 \\
\hline 100 & 0,0017 & $\mathrm{BBB}+$ & 0,230221 & $-1,648$ & 0,219 & 0,425 & 42,547 & 3,4038 & 0,0765 \\
\hline 100 & 0,0255 & $B+$ & 0,153532 & $-0,805$ & 0,102 & 1,302 & 130,19 & 10,4151 & 1,1475 \\
\hline
\end{tabular}

Tab. 6 - Capital requirements using Foundation Internal Rating Based Approach. Source: Own Source

\begin{tabular}{|c|c|c|c|c|c|c|c|c|c|}
\hline & LGD & 0,45 & & & & & & & \\
\hline & maturity & 2,5 & & & & & & & \\
\hline EAD & PD (\%) & rating & $\begin{array}{c}\text { Correla- } \\
\text { tion }\end{array}$ & $\mathrm{N}(\mathrm{x})$ & b & RW & RWA & $\begin{array}{c}\text { Capital } \\
\text { ad- } \\
\text { equacy }\end{array}$ & $\mathrm{EL}=\mathrm{PD} * \mathrm{LGD}$ \\
\hline 100 & 0,0001 & $\mathrm{AAA}$ & 0,239401 & $-2,531$ & 0,388 & 0,133 & 13,307 & 1,06455 & 0,0075 \\
\hline 100 & 0,0006 & $\mathrm{~A}+$ & 0,236453 & $-1,987$ & 0,276 & 0,387 & 38,728 & 3,09822 & 0,045 \\
\hline 100 & 0,0017 & $\mathrm{BBB}+$ & 0,230221 & $-1,648$ & 0,219 & 0,709 & 70,912 & 5,67299 & 0,1275 \\
\hline 100 & 0,0255 & $B+$ & 0,153532 & $-0,805$ & 0,102 & 2,17 & 216,98 & 17,358 & 1,9125 \\
\hline
\end{tabular}


Complete results of each method are shown in the final table as follows:

Tab. 7 - Capital adequacy as the result of three approaches of credit risk management. Source: Own Source

\begin{tabular}{|c|c|c|c|c|c|}
\hline \multicolumn{6}{|c|}{ Capital adequacy in mil. Kč } \\
\hline Rating & PD (\%) & $\begin{array}{l}\text { Standardized } \\
\text { approach with- } \\
\text { out assigned } \\
\text { external rating }\end{array}$ & $\begin{array}{c}\text { Standardized } \\
\text { approach }\end{array}$ & $\begin{array}{c}\text { Foundation } \\
\text { Internal Rat- } \\
\text { ings - Based } \\
\text { Approach }\end{array}$ & $\begin{array}{c}\text { Difference } \\
\text { between } \\
\text { FIRB and } \\
\text { STA ap- } \\
\text { proaches }\end{array}$ \\
\hline AAA & 0 & 8 & 1,6 & 0,2386 & $97,02 \%$ \\
\hline AA+ & 0 & 8 & 1,6 & 0,2387 & $97,02 \%$ \\
\hline AA & 0,01 & 8 & 1,6 & 0,6387 & $92,02 \%$ \\
\hline AA- & 0,03 & 8 & 1,6 & 1,2248 & $84,69 \%$ \\
\hline$A+$ & 0,05 & 8 & 1,6 & 1,4664 & $81,67 \%$ \\
\hline A & 0,07 & 8 & 4 & 2,0379 & $74,53 \%$ \\
\hline A- & 0,08 & 8 & 4 & 2,2058 & $72,43 \%$ \\
\hline BBB+ & 0,16 & 8 & 4 & 3,2906 & $58,87 \%$ \\
\hline BBB & 0,26 & 8 & 8 & 4,2825 & $46,47 \%$ \\
\hline BBB- & 0,31 & 8 & 8 & 4,689 & $41,39 \%$ \\
\hline $\mathrm{BB}+$ & 0,67 & 8 & 8 & 6,7043 & $16,20 \%$ \\
\hline BB & 0,88 & 8 & 8 & 7,469 & $6,64 \%$ \\
\hline BB- & 1,47 & 8 & 8 & 8,8989 & $-11,24 \%$ \\
\hline B+ & 2,47 & 8 & 8 & 10,325 & $-29,06 \%$ \\
\hline B & 7,17 & 8 & 12 & 14,449 & $-80,61 \%$ \\
\hline B- & 9,99 & 8 & 12 & 16,368 & $-104,60 \%$ \\
\hline $\mathrm{CCC} / \mathrm{C}$ & 23,56 & 8 & 12 & 20,222 & $-152,78 \%$ \\
\hline
\end{tabular}

In the case of our simulated portfolio, effect of different credit risk approaches and their function can be seen in Fig. 7. Differences of these measurements are very striking at the final output in the form of capital requirements. For the credit risk measurements mathematical formulas set by regulator (nr. 1, 2, 3, 4, 5, 6 and 7) have been used.

Our results have showed that advanced methods for credit risk measurement are more flexible on class change of corporate exposures in portfolio. On the one hand The Standardized approach without assigned external rating is the most used method in the Czech Republic on the other hand the capital requirement at 8 mil. Kč has been calculated as the highest value and holds at the same level regardless of the portfolio composition's quality. The Standardized approach with assigned external rating (STA) has worked out a much lower capital adequacy than The Standardized approach without assigned external rating. The reason is the fact that after 
regulator's approval banks may use external agency's degrees (see Table 3) and subsequently the risk weights could be assigned (see Table 1).

Method which has calculated the lowest amounts of capital requirement is the Foundation Internal Ratings - Based Approach (FIRB), which alone from among examined methods has a possibility to determine the parameters according bank's own estimates. We could observed that if exposures in its portfolio have given no worse than BB rating (probability of default is 0,88\%), saving capital between FIRB and the most used method in the Czech Republic has been varied from $97 \%$ to $7 \%$, which give us very surprising results. The first reason is risk weight which is based on the creditworthiness of exposure. Better quality of exposure, the risk weight would be lower. Second reason is the own probability of default of each exposure, which is valued on the basis of at least 5 years of previous historical data. This means that estimates are more accurate and tailored to the specific bank. Basel III gives to bank a opportunity to handle with own security and profitability at the same time. However, at the same time, we are getting to the interesting situation where on the one hand, banks are gradually appreciated to hold higher-quality exposures in their portfolio by means of its own estimates. On the other hand, there is arising a question whether such a lucrative difference between the approaches and the transition to the own-esteem exposure would not print a distortion ratings for themselves as they did before the financial crises with off balance sheet securitization assets has been started.

Results can be seen in graphic design as follows:

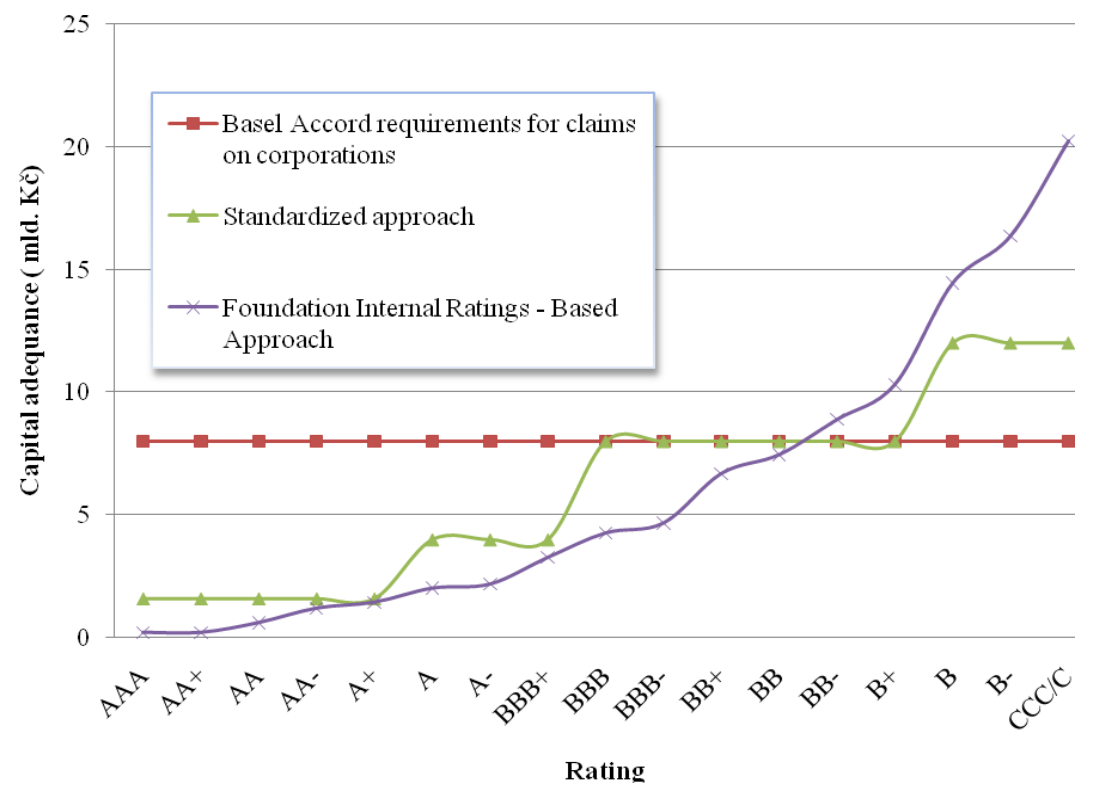

Fig. 4 - Comparison of Total Capital Requirements for Corporations by three approaches of credit risk management. Source: Own Source 
Results of analysis showed that although the Basel III standardized method is the simplest, capital is most difficult. Using advanced methods showed that increasing model complexity is reduced capital requirement. Here the question arises as to consult the bank with this anomaly and whether to accept the anomalies at the expense of higher capital requirement.

\section{DISCUSSION}

New banking regulations known as Basel III mean requirements of significant increase of equity amount for banks. Our research highlighted the fact that transition from the STA approach to FIRB approach a significant minimization effect is represented and significant savings of bank's equity is brought.

Stable work of financial systems is a very complex issue. The reason is, that methods, which are used for credit risk measuring risk are not reliable and have many imperfections. Today, widespread statistical methods for measuring and predicting risk are contributing to the procyclical changes in the financial system. Management models represent efforts to define the complex economic processes through mathematical models. However, these sophisticated methods can not accurately show the complexity of the economic system despite their sophistication. The credit crisis has shown that the current approach to capital adequacy of banks is too narrow. Banks tend to behave the same - investing in similar assets, undergoing identical risks etc. Basel III seeks to achieve more comprehensive and more countercyclical regulatory framework. The new rules bring an interesting idea of "capital cushions" at 2.5 percent above the regulatory minimum. This should serve to cover additional losses when the economy will flourish. If banks could not meet the countercyclical cushion, they would be exposed to restrictions on dividends and bonuses. Basel III should prevent the banks to dissolve the profits between shareholders and managers, without strengthen the capital at the same time. In conclusion we must realize that even if the new rules brought in effects that are expected of them, it will not mean that the banking crisis will be history. The basic problem is always above the other assets that banks hold at the moment.

Basel III brings demand for significant capital equity growth for banks. According to the study (McKinsey \& Company, 2010) proposed changes to the Tier 1 composition would probably cause a significant deficiency of 700 EUR in European banking capital, which represents 40 $\%$ increase in core Tier 1 equity. If proposed leverage ratio would be adopted, up to $70 \%$ of equity growth Tier 1 would be required. New liquidity standards would supposedly represent a increase of long-term financing from 3,5 to 5,5,trillion EUR and 2 trillion EUR in highly liquid assets have to be hold by banks.

\section{CONCLUSION}

Within the focus of this article, basic research to compare credit risk approach in commercial bank under Basel III has been carried out and changes in the regulatory capital amount using different risk weighted functions of basic and advanced methods for credit risk management 
under Basel II has been quantified by changing of the corporate portfolio structure from the most creditworthy to defaulted exposures.

Our results have showed that advanced methods for credit risk measurement are more flexible on class change of corporate exposures in portfolio. On the one hand The Standardized approach without assigned external rating is the most used method in the Czech Republic on the other hand the capital requirement at 8 mil. Kč has been calculated as the highest value. The Standardized approach with assigned external rating has worked out a much lower capital adequacy than The Standardized approach without assigned external rating. The reason is the fact that after regulator's approval banks may use external agency's degrees and subsequently the risk weights could be assigned. Method which has calculated the lowest amounts of capital requirement is the Foundation Internal Ratings Based Approach (FIRB), which alone from among examined methods has a possibility to determine the parameters according bank's own estimates. Based on our research, we concluded that if bank's portfolio have given exposures with no worse than $0,88 \%$ probability of default, saving capital between FIRB and the most used method in the Czech Republic has been varied from $90 \%$ to $10 \%$ approximately, which give us very surprising results.

The overall impact on the estimated cost of European banks is forecasted at 190 billion EUR, from which, 40 billion EUR impact of costs on the additional financing is represented and 150 billion EUR cost are necessary to meet the proposed capital requirements (McKinsey \& Company, 2010). Suggestions of Basel III could result in ROE reduction about $5 \%$ (excluding the effects of banking sector minimization). Banks would probably have to give up profits for 3-4 years. Implementation of Basel III rules may have some others negative consequences for example on the interbank market, on lending capacity in the range from 1,2 o 2,5 trillion EUR, and even on decrease of financial system stability.

\section{Acknowledgements}

This paper was supported by Project No. IGA/FaME/2012/12: Optimization of internal rating model parameters of commercial banks in the small and medium enterprises.

\section{References}

1. Annual Global Corporate Default Study And Rating Transitions (2010). Standard \& Poor's [online]. 2010 [cit. 2012-03-20]. Retrieved from: http://www.standardandpoors.com/ratings/articles/en/us/?articleType=HTML\&assetID=1245302234237

2. Basel Committee on banking supervision (2005). International Convergence of Capital Measurements and Capital Standards. A revised framework, Basel.

3. Basel Committee on banking supervision (2006). International Convergence of Capital Measurement and Capital Standards; A Revised Framework; Bank for International Settlements

4. Belás, J., \& Cipovová, E. (2011). Internal Model of Commercial Bank as an Instrument for Measuring Credit Risk of the Borrower in Relation to Financial Performance (Credit Scoring and Bankruptcy Models). Journal of Competitiveness, 3 (4), 104 - 120.

5. Belás, J. et al. (2010). Management komerčných bánk bankových obchodov a operácií. Žilina: Georg Žilina. 
6. Česká republika (2007). Č. 123/2007 Sb. In: Cturtý díl: Kapitálová prǐměrenost. 2007. Retrieved from: http://www.cnb.cz/miranda2/export/sites/www.cnb.cz/cs/legislativa/obezretne_ podnikani/download/vyhlaska_para_cast_4.pdf

7. Česká republika (2007a). Kategorie expozic a riz̨ikové váhy prí poư̌ivání standardizovaného prìstupu. In: Př́loha č. 11 č. 123/2007 Sb. Retrieved from: http://www.cnb.cz/miranda2/export/sites/ www.cnb.cz/cs/legislativa/obezretne_podnikani/download/vyhlaska_priloha_04.pdf

8. Česká republika (2007b). Parametry v rámci prǐstupu IRB. In: Př́loha č. 13 č. 123/2007 Sb. Retrieved from: http://www.cnb.cz/miranda2/export/sites/www.cnb.cz/cs/legislativa/obezretne_podnikani/download/vyhlaska_priloha_13.pdf

9. Česká republika (2002). Pravidla pro posuzováni pobledávek ₹ finančních činností, tvorbu opravných polo:̌ek a rezerv a pravidla pro nabýváni něketerých drubư aktiv. In: č. 9/2002 Věst. ČNB. Retrieved from: http://www.cnb.cz/miranda2/export/sites/www.cnb.cz/cs/legislativa/vestnik/2004/ download/v_2004_18_10804530.pdf

10. Česká republika (2007c). Zpuisoby výpočtu hodnoty riz̨ikově vážené expozice v rámci prístupu IRB. In: Př́loha č. 12 č. 123/2007 Sb. Retrieved from: http://www.cnb.cz/miranda2/export/sites/ www.cnb.cz/cs/legislativa/obezretne_podnikani/download/vyhlaska_priloha_12.pdf

11. Conford, A. (2005). Basel II the revised framework of june 2004. United Nations Conference on Trade and Development, no. 178. Retrieved from: http://archive.unctad.org/en/docs/osgdp20052_en.pdf

12. Härle, P., Heuser, M., Pfetsch, S., \& Poppensieker, T. (2010). Basel III. What the draft proposals might mean for European banking. Banking \& Securities. Mnichov: McKinsey \& Company.

13. Holman, R. (2009). Budoucnost kapitálové regulace bank. In [online]. Retrieved from: <http:// bankovnictvi.ihned.cz/c4-10066470-37195110-900000_d-budoucnost-kapitalove-regulacebank>.

14. Knápková, A., \& Pavelková, D.(2010). Finančni analýza. Komplexní průvodce s př́klady. Praha: Grada Publishing.

15. Pilch, C.(2010). Metódy riadenia bankových rižík [online]. Metódy úverového rizika, s. . Retrieved from: http://www.derivat.sk/

16. Polouček, S. (2006). Bankovnictví. Praha: C.H.Beck.

17. Sivák, R. (2006). Teória a prax vybraných drubov finančných rizík: (keditné, trbové, operačné). Bratislava: Sprint.

18. Slovenská sporitel’ňa (2010). Bazilej II. v kocke - v̌̌etko o nových predpisoch o kapitálovej primeranosti v prehladnej brožure [online]. Retrieved from: <http://www.slsp.sk/downloads/bazilej2_ sk.pdf $>$. 


\section{Contact information}

Ing. Eva Cipovová

Tomas Bata University in Zlin, Faculty of Management and Economics

Mostni 5139, 76001 Zlín, Czech Republic

Tel: +420576032854

Email: cipovova@fame.utb.cr.

doc. Ing. Jaroslav Belás, PhD.

Tomas Bata University in Zlin, Faculty of Management and Economics

Mostni 5139, 76001 Zlin, Cqech Republic

Tel: +420 576032410

JEL Classification: G01, G21, G24, C52 